\title{
THE MOSAICS OF THE «HOUSE OF AION» AT NEA PAPHOS: THE PALINGENESIA OF THE ROMAN EMPIRE IN 348 A. D. DURING THE CONFLICT BETWEEN PAGANISM AND CHRISTIANITY IN THE EAST
}

The mosaics of the «House of Aion» at Nea Paphos discovered in 1983 represent: (a) Leda with Zeus in form of a swan; (b) Dionysus as infant in the lap of Hermes; (c) the beauty contest between Cassiopeia, queen of Aethiopia and mother of Andromeda, and the Nereids with Aion, Sol and Luna presiding as judges; (d) a Dionysiac procession consisting of Maenads and Satyrs; (e) the judgment of Marsyas whose pride in his mastery of the aulos resulted in hybris against Apollo.

Following a survey of the dating of the mosaics and the possible historical context in which they were created, the interpretation of the images is discussed based on numerous parallels in monuments and literary texts. The handling of the Cassiopaea myth is compared with Lucian (Dial. Mar. 14, 4). The Dionysos' mysteries and the birth of Dioscuri are seen as a reflection of the cult of the Roman god Aion, and its connection with the Ludi saeculares is discussed: the games probably date to 348 A. D., when Constantius II celebrated the jubilee of Rome. The presence of Aion on the central panel would then reflect the conflict between Pagans and Christians in Cyprus.

Key words: Cyprus, «House of Aion» at Nea Paphos, Roman god Aion, Ludi saeculares, mosaics, Leda, Zeus, Dionysus, Cassiopeia, Nereids, Maenads, Satyrs, Marsyas.

Феодор Маврояннис

(Кипрский университет)

\section{Мозаики из «Дома Эона» в Неа-Пафосе: palingenesia Римской империи в 348 г. и противостояние на Востоке язычества и христианства}

Найденные в 1983 г. мозаики из триклиния римского дома изображают (a) Леду и Зевса в виде лебедя, (b) младенца Диониса на коленях у Гермеса, (d) процессию сатиров и менад Диониса, а также (e) суд над сатиром Марсием. В центре мозаики (c) представлен суд о красоте Кассиопеи, царицы Эфиопии (матери Андромеды) и кипрской Нереиды, причем Эон, Солнце и Луна отдают предпочтение Нереиде.

Автор интерпретирует мозаики на основе сопоставлений как с памятниками изобразительного искусства, так и с литературными текстами: изображенный вариант мифа о Кассиопее автор возводит к Лукиану (Lucian. Dial. Mar. 14, 4), мистерии Диониса и Диоскуры могут отражать культ римского Эона (Aion) и празднование на Востоке им- 
перии юбилея Рима. Подробно рассматривается празднование Ludi saeculares (датируются 348 г.) и предполагается, что Констаций II отмечал их в условиях религиозного примирения, закрепленного Медиоланским эдиктом.

Ключевые слова: Кипр, «Дом Эона» в Неа-Пафос, культ Эона (Aion) в Римской империи, Ludi saeculares, мозаики, Леда, Зевс, младенец Дионис, процессия сатиров и менад, суд над Марсием, Кассиопея, Нереиды.

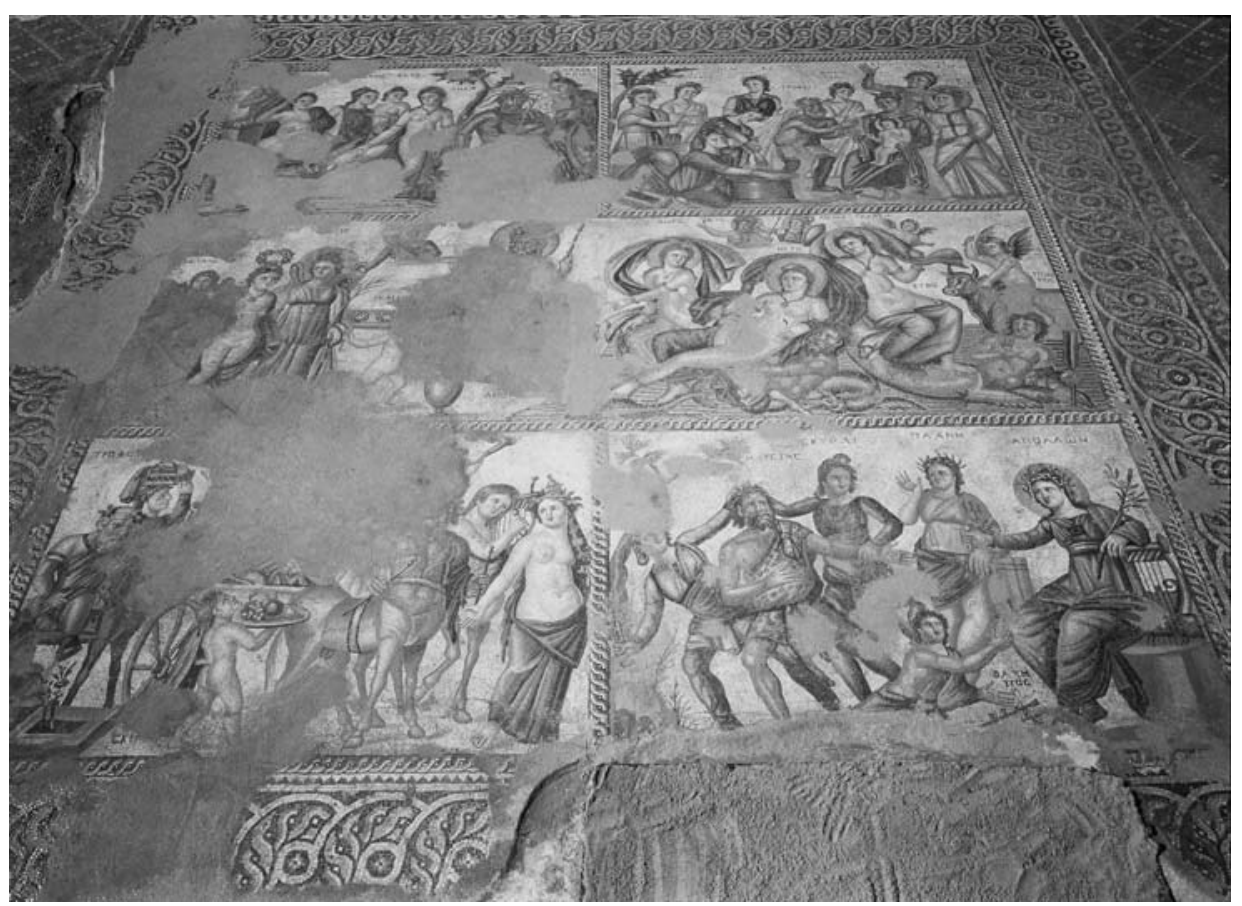

Table 1. Mosaics from the «House of Aion» at Nea Paphos.

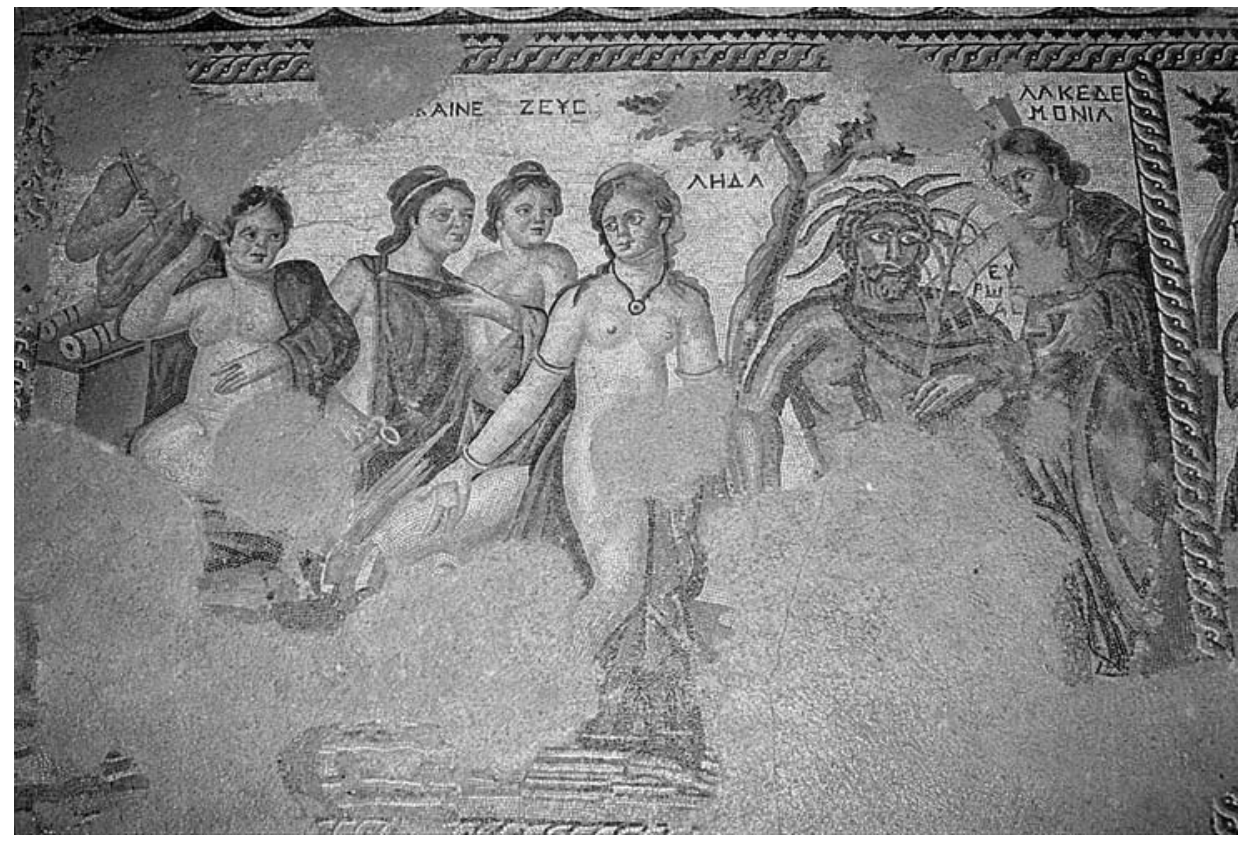

Table 2. (a) Leda with Zeus in form of a swan. 


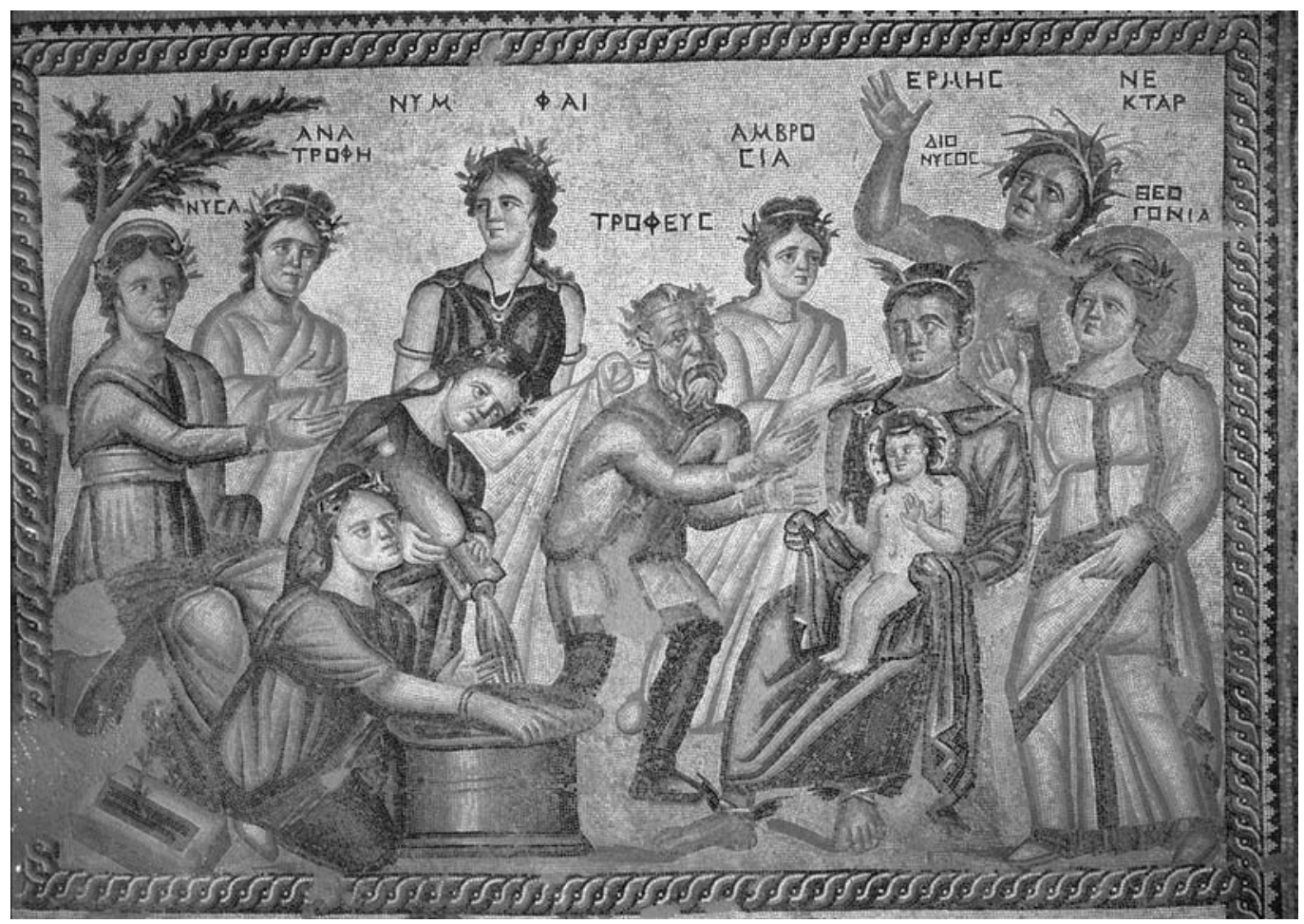

Table 3. (b) Dionysus as infant sitting on Hermes' lap.

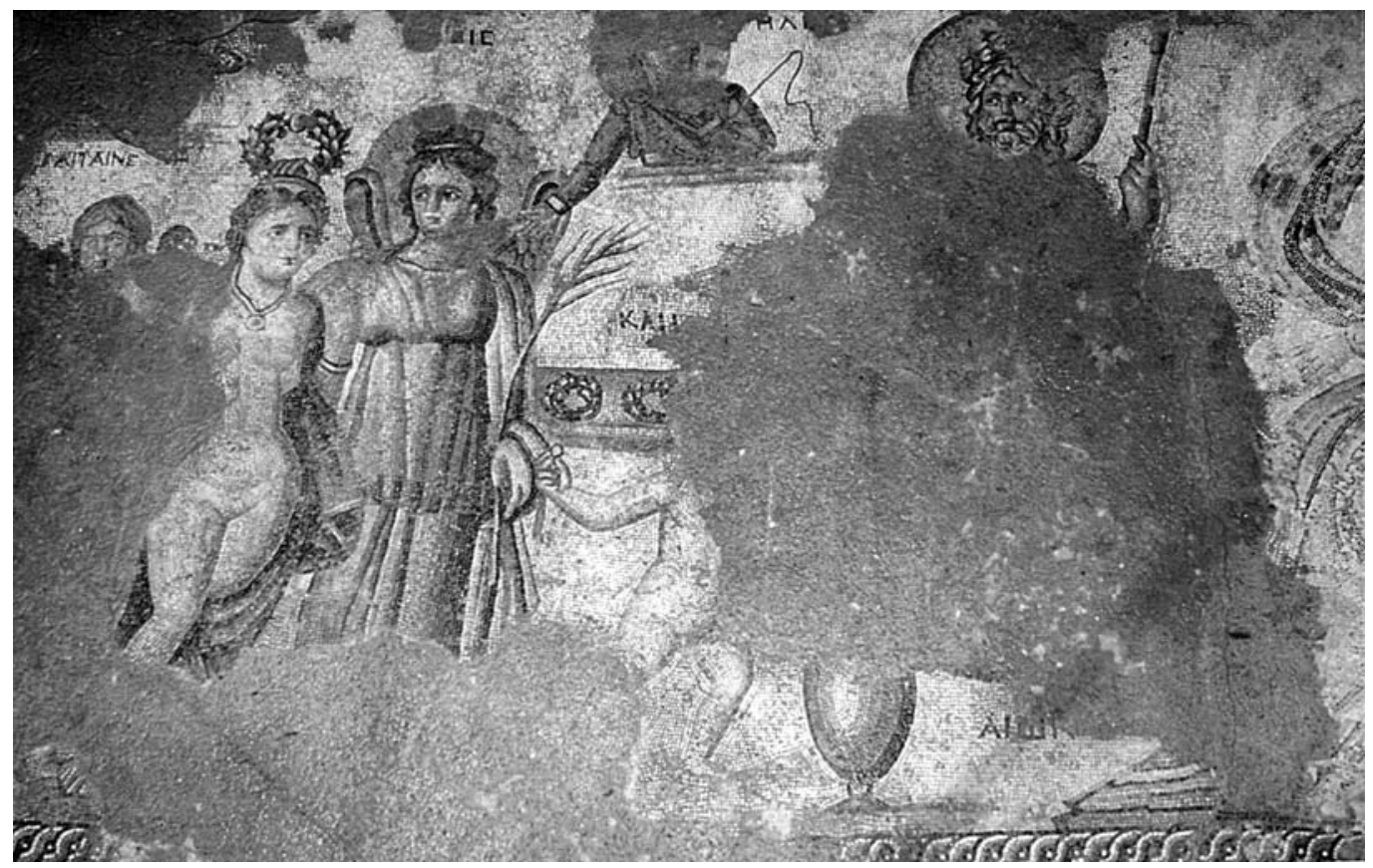

Table 4. (c) Contest between Cassiopeia and a Nereid 


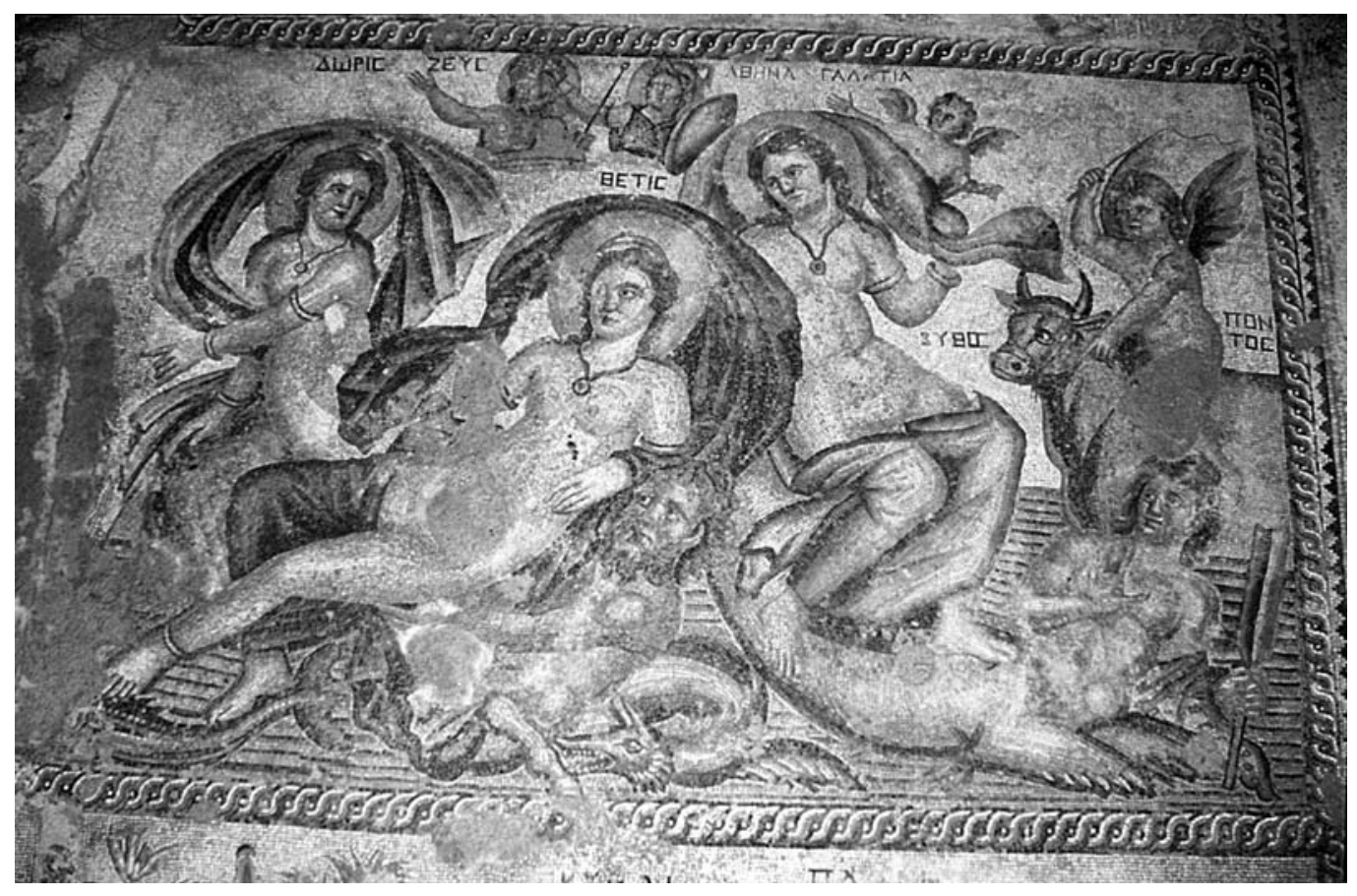

Table 5. (c) The Nereids (Doris, Thetis, Galateia), Zeus, Athena, Pontus

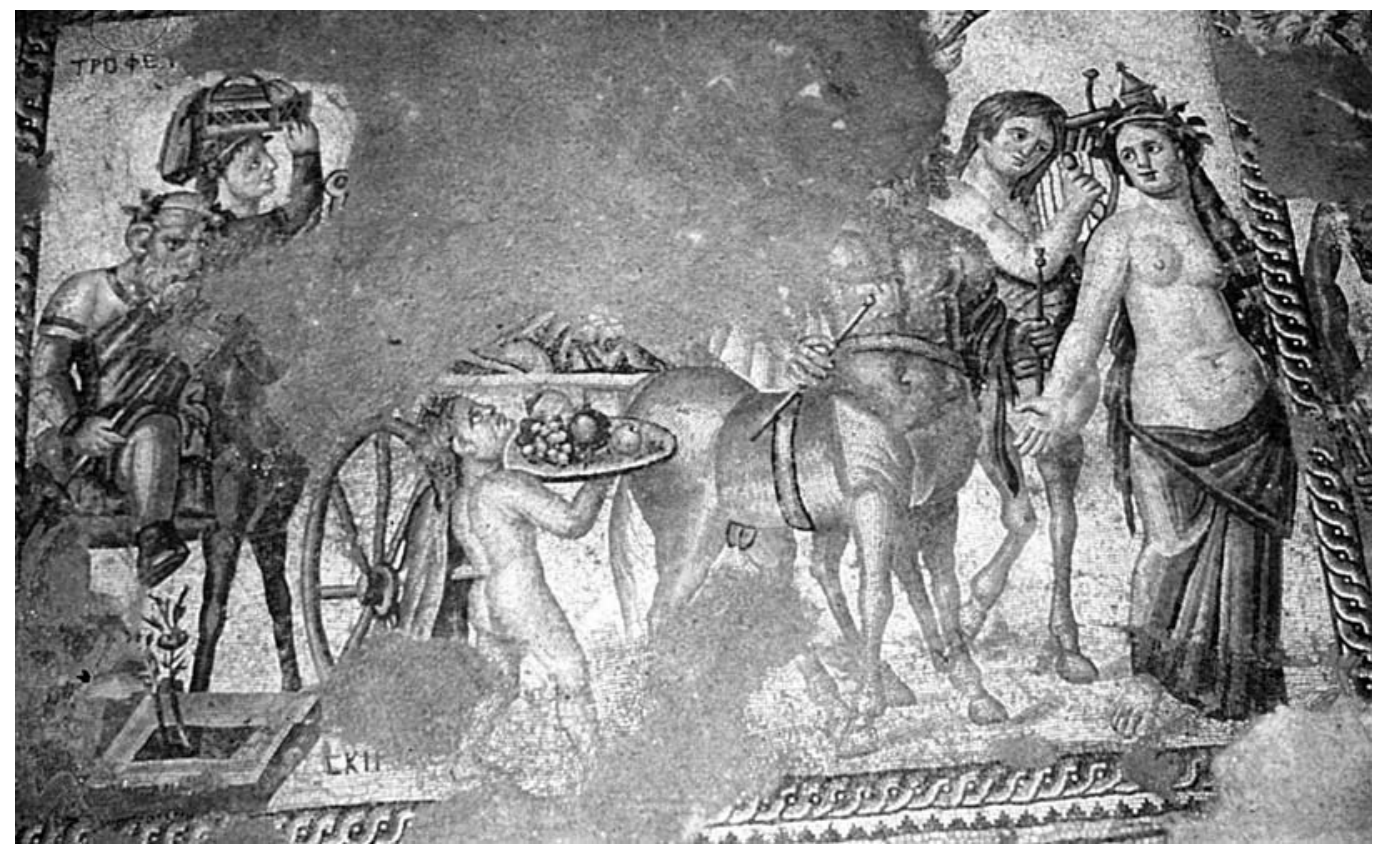

Table 6. (d) Dionysiac procession consisting of Maenads and Satyrs. 


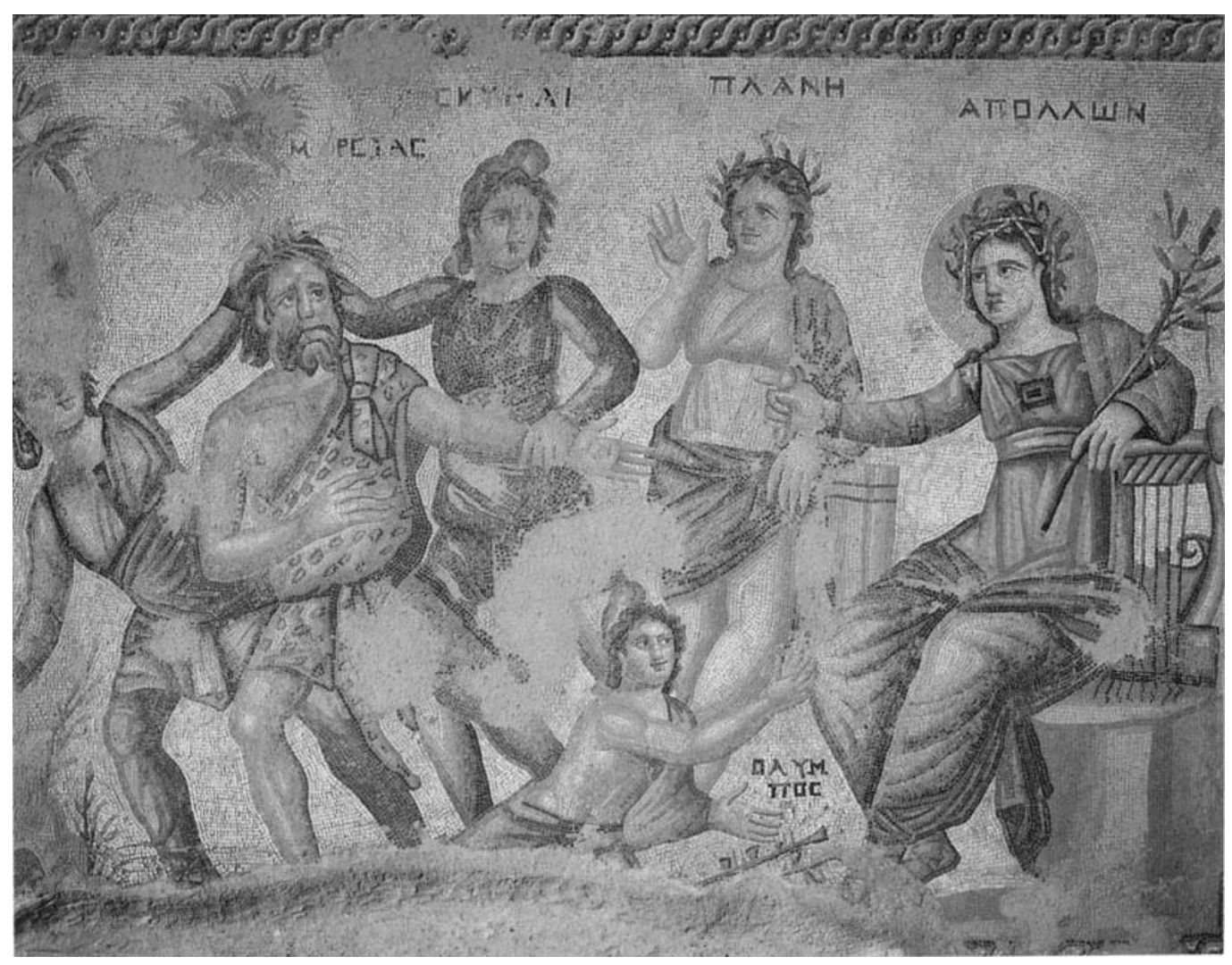

Table 7. (d) Judgment of Marsyas.

\section{A) The Mosaics}

The mosaics of the «House of Aion» at Nea Paphos hold a favourable place in the literature of Late Roman art and culture, far beyond their place of origin within the small province of Cyprus, for the mythological scenes depicted on five marvellous panels are so characteristically imbued to the Graeco-Roman culture that they gave rise to several ingenious interpretations. The Polish mission unearthed in 1983 a singular room - triclinium - dining room (68 $\mathrm{m}^{2}$ ) of a large «Roman House» entered directly from the street and covered $\left(16 \mathrm{~m}^{2}\right)$ with a series of mosaics whose interpretation is, still, pending. According to a vertical arrangement, the Mosaics include 2 panels in the upper part -1 central developed panel -2 panels in the lower part, all with scenes of characteristic myths: (a) up left: Leda with Zeus in the form of a swan; (b) up right: Dionysus as infant in the lap of Hermes, at the presence of Anatrophe and Tropheus; (c) central: the competition between Cassiopeia, queen of Aethiopia and mother of Andromeda, with the Nereids over a judgement of Beauty, astonishingly won by the Cypriot Nereid under the presence of Aion, Sol and Luna; (d) low 
left: a procession of a Dionysiac thiasos consisting of Maenads and satyrs; (e) low right: the judgment of Marsyas who, proud of himself for his mastery of the aulos, provoked the hybris against Apollo. Unfortunately, all the interpretations are in line with the $19^{\text {th }}$ century tradition of learned societies of erudite studies, which sought to solve riddles, rather than to explain what figured culture is and how culture is affected by art and literacy. Even if these mosaics do convey in their entirety a deeper and higher level of values, in transcending the naturalism of the images and tending to perceive the Invisible ${ }^{1}$, there is a first and fundamental level of lecture to be followed: The one focused on the iconography and the literary versions of the myths which could give rise to a second empirical level, that of the moral paradigms in the Age of conflict between Paganism and Christianity. It would be inaccurate to assume that there was not any kind of research or even some certainties about the destiny of the individual's soul, but the more invisible the metaphysical sphere is, the more difficult it becomes to prove allegories. Thus, there must have been a multiple level reading, giving priority to the political meanings inherent to the perspective of a more expanded concept of «renaissance». This two-fold idea seems to be dominant in all the levels of lecture of the Mosaics, both as a private and as a public message. It cannot have been within the intentions of the owner of the House at Nea Paphos to create any complexes of illiteracy to his hosts. Instead, he must have settled down some common principles identifying the culture of an upperclass member within the structure of a very refined Pagan society. W. Daszewski who preferred among the whole composition to interpret the scene of Dionysos as an infant in the lap of Hermes, by considering it in a metaphysical sense as a promise for the salvation of the human soul through Dionysos, did attempt to bring into light the most profound essence of the culture of that Age, namely the necessity emerging for the Pagans to face with valid arguments the spreading of Christianity in Cyprus ${ }^{2}$. G. Bowersock considered as a valid method to start by commenting on the hold of Dionysos in the Late Cypriot society through Nonnus' Dionysiaca, written in Pagan

\footnotetext{
${ }^{1}$ Bianchi Bandinelli 1981³: 16-19; Plot. Enneads I, 4, 14; Enneads V, 8, 1; 'Quanto più la materia perde forma, tanto più è simile al modello originale'; cf. Saint Paul: 'il visibile non è che un velo posto dinanzi all'invisibile'.

${ }^{2}$ Daszewski 1985: 38-45; Parrish 1995: 307-32; against his interpretation, Deckers1986: 145-172.
} 
Beirut around 450 A. D. However, this is only the latest representation in the iconographic tradition of New Dionysos who might be already created at Nea Paphos a century earlier. For G. Bowersock, as well, the scenes of Dionysos in the «House of Aion» were not fashion instances or mere repetition of content gaps, but a conscious response to Christianity through adequate pagan motives. The visibility of their meanings must have been therefore clear ${ }^{3}$. More adapted to the philosophical trends of this Age, the remarks of J. Balty traced a Neo-Platonic background for the «House of Aion», into which the heretical doctrine of Arianism would have found its privileged space even after the sentence against Areius at Nicaea in 325 A. D. Accordingly, she acknowledges that certain Monotheistic qualities present in the teaching of Plotinus were applied in an intentional way to the figurative program of the «House of Aion», as a response of the Cypriot Pagans towards Christians ${ }^{4}$. A conflict was to be expected, if we consider the literary production of that time. However, a question arises: had the hosts of the "House of Aion» read the Symposium of Plato, the Enneads of Plotinus or known the Neo-Platonic synthesis of Jamblichus in the first half of the $4^{\text {th }} \mathrm{c}$. A. D., before entering that House? On his part, M. Olszewski is convinced to have decodified the system ${ }^{5}$, by building up a theory based on the rules of the rhetorical art under the Empire, which were astonishingly transferred from the $2^{\text {nd }}$ c. A. D. to the $4^{\text {th }}$ c. A. D. Allegory, analogy, personification and the antithetic syntaxis would then be detectable in the composition. This could be a stroke of genius, but also a spirit-inspired speculation. He, too, descends into the political arena, as he reduces, in fact, the composition to the level of a severe critique against the principles of Christians. More recently, E. La Rocca, returned to the iconography of Dionysos, by reconsidering the value of implicit Christian patterns, without, however, commenting on the rest of the panels ${ }^{6}$. His idea that the mythical patterns go back perhaps to a Ptolemaic model rendering Ptolemy III Euergetes and Ptolemy IV Philopator as Hermes and Dionysos fails to be confirmed, even if Ptolemy III Euergetes made the dedication of the temple of Thoth - Hermes in his sanctuary at Hermoupolis Magna. If Alexandria has something to do with Nea Paphos during the Imperial times, this is Roman Alexandria, not

\footnotetext{
${ }^{3}$ Bowersock 1990, Ch. IV: 41-53, 49.

${ }_{5}^{4}$ Balty 1995.

${ }^{5}$ Olszewski 2020: 221-250; 2013: 207-239.

${ }^{6}$ La Rocca 2021; cf. Fowden 1986.
} 
Ptolemaic. The problem of the transition from Paganism to Christianity $^{7}$, as it is at hand through the Cypriot evidence, is enormous, since we cannot easily perceive by the material culture its original ideological character, whether the procedure was polemic, antagonistic or conflictual, rather than smooth and syncretistic.

\section{B) The chronology of the Mosaics}

It is outstanding that we can delimitate the dating of the Mosaics within the years between the rising of the Roman praetorium praesidis, after the reforms of Diocletian and the building of the Basilica of Chrysopolitissa at Nea Paphos. The transition is a historical problem of political history, even if, at the same time, it becomes a cultural and social phenomenon, touching upon concrete religious cases which may prove enlightening towards the transformation of the society in Cyprus between 340 and 390 A. D. Concerning the issue of the main political character of this Age, the chronology of the "House of Aion» can be specified without any doubt: The Mosaics belong to the period between 335 and 350 A. D., still in the time of the declared institutional equity of political rights between Paganism and Christianity after the Edict of Mediolanum. This is a fact, not only because I have already pointed out on archaeological reasons that the adjacent «House of Theseus» is to be dated between the final years of Constantine and the early years of his son Constantius II $^{8}$, but also because, and even if metaphysics prevails in some sort of interpretation, the spiritual trends must be arranged within a concrete historical framework. Far from philosophical speculations, it is significant to underline Constantius' II political behaviour. Neoplatonism, Arianism or Hermetism, whatever had been the source of inspiration, they need to be historically identified, behind any gesture in the iconograpy, version of the myths or moral example. The «House of Theseus» and the

\footnotetext{
${ }^{7}$ In a recently published volume, the transition to Christianity is to be retraced on the grounds of the «House of Eustolios», not at all from the «House of Aion» on. Except from the fact that the Editor did not consider worthy of mention my study on the «House of Eustolius», which is accepted by the Department of Antiquities of Cyprus, as regards its chronology, to be put around $435 \mathrm{~A}$. D. as I have extensively proofed, there is a protracted confusion between the $4^{\text {th }} \mathrm{c}$. A. D. and the $5^{\text {th }} \mathrm{c}$. A. D., not less than a consistent lack of basic notions of what is meant «Roman» in the East; Nasrallah, Luijendik, Bakirtzis (eds.) 2020.

${ }^{8}$ Micocka 2013: 117-134; Mavrojannis 2016: 323-347.
} 
«House of Aion» occupy interconnected insulae within a basic Hippodamian ground plan. Whether this is the result of the reconstruction after the earthquake of 333 or after that one of 343 A. D., still remains open. More probably it is a date soon after 343 A. D., which is either to be confirmed or rejected. At any rate, a coin of Licinius found under the pavement of the Mosaic of Aion, often mentioned as some kind of determinant proof in dating the «House», does not have any more weight than as a generic terminus post quem. A single coin cannot overwhelm the monumental evidence. The necessity to be precise at this point is imperative, in order to draw some valuable conclusions on history as well as on artistic culture. Thus, it is essential to turn to what we have at our disposal, that is myths.

\section{C) The Myth of Cassiopeia ${ }^{9}$}

The preeminent panel is displayed at the center of the composition between two couples of panels which are horizontally arranged, below and above the central scene, and covered the triclinium of the «House». It is, therefore, suitable to use for the Kallisteia among the Nereids, the term «Main panel», which imposes, as method necessitates, to start any consideration by the overwhelming subject. The panels are independent, separated from each other through decorative frames, without any evident connection between them. However, there seems to exist some clear geometric structure, as if an inherent organic coherence ruled upon the single parts of the composition. An irrational criterion of interpretation has prevailed against this formal order. Threre would be represented profound philosophical meanings rendering as many abstract as mystic concepts which would be perceived only by initiated persons, today, as well as in the intentions of the owners of the «House of Aion» in Antiquity. It is astonishing enough that even E. La Rocca gave pre-eminency to the mythological scene of Dionysos, although the main subject is the Games of beauty. A lot of confusion was yielded by the attempt to identify the right literary version and to assign a role to each personality bearing an inscription. Among the female persons emerges Cassiopeia while she is being crowned. In the main scene there is a thiasos of some Nereids, which is represented at a highest level through Thetis, Doris and Galateia. This does not allow to overlook the fact that the

${ }^{9}$ Balty 1981: 95-10; Faulkner 2017: 105 and note 7. 
central figure who has undertaken the role of the judge is Aion. Recently, T. Kaiser brought into light the literary version from the Bibliotheca of Apollodorus, so, he was to identify the figures in the landscapes of Phoenicia and Palaestina ${ }^{10}$. It should be noted that the version of Apollodorus cannot have constituted the source of inspiration for the mosaic, because in this version Cassiopeia will be punished for her arrogance, for having challenged the Nereids. Anyway, when Apollodorus asserts that «Arriving in Ethiopia, which was ruled by Cepheus, [Perseus] found the king's daughter Andromeda exposed as prey to a sea monster; for Cassiepeia, the wife of Cepheus had claimed to rivel the Nereids in beauty, boasting that she surpassed them all», he knows that Cepheus has a Cypriot personality, as founder of Keryneia, and Cassiepeia was the wife of the Aethiopians - Cypriots, according to a known passage of Herodotus, recalling the Aethiopian roots of some Cypriots, namely the inhabitants of Amathous (Hdt. VII 90). It is a symptomatic example of hybris like the hybris of Marsyas against Apollon. Here, the presence of $\Pi \Lambda \mathrm{ANH}$ seems to be a reminder of the Hermetic religion. The supporters of Hermetism taught that God was intangible, unborn, eternal, unchanged, identified with the agathon, which was his proper name, as well as Creative and Father. Hermetics consider that only themselves held the truth, whereas all

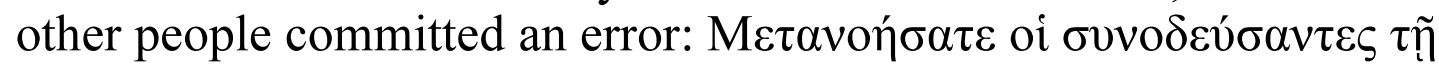

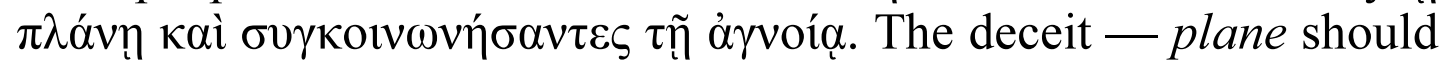

${ }^{10}$ Apollod. Bibl., II 4, 3: «Arriving in Ethiopia, which was ruled by Cepheus, [Perseus] found the king's daughter Andromeda exposed as prey to a sea monster; for Cassiepeia, the wife of Cepheus had claimed to rivel the Nereids in beauty, boasting that she surpassed them all. The Nereids were enraged by this, and Poseidon, who shared their anger, sent a seaflood and a monster against the land. Now Ammon had prophesied deliverance from this calamity if Cepheus' daughter Andromeda were offered as prey to the monster, and compelled by the Ethiopians, Cepheus had done so and tied his daughter to a rock. As soon as Perseus as saw her, he fell in love, and promised Cepheus that he would destroy the monster if he gave him the rescued girl as a wife. When oaths had been sworn to effect, Perseus confronted the monster and killed it, and set Andromeda free. Phineus, however, who was a brother of Cepheus and had been promised Andromeda beforehand, plotted against Perseus; but when Perseus learned of the conspiracy, he showed the Gorgon to Phineus and his fellow plotters, turning them to stone on the spot»; cf. Ovid. Metam. IV 604-803, esp. IV 668-701; cf. Strabo I 2, 35 = C 42-43; Kaiser 2011: 323339. 
justify the choice of Marsyas and Apollo in our composition as a Hermetic message. According to the schema of boasting that Cassiepeia would be more beautiful than the Nereids, there is the Mosaic of Palmyra (National Museum of Damascus, 220-230 A. D.), discovered in a house behind the Temple of Bel, where the familiar story of Cassiepeia, as the most beautiful of all, is portrayed. And yet, the version of Nea Paphos is overturned: Cassiopeia not only surveys, without punishment, but she wins in the festival of beauty. G. Bowersock had noted how difficult it is to find the reason for such a radical transformation and moreover where its legitimacy lies, a privilege which would have allowed Cassiopeia to reach from a lower level to the highest rank among the Nereids. No ancient author mentions anything similar, except for a passage of Lucian of Samosata in his «Dialogues of the Sea-Gods», in which he reveals a completely different attitude towards the idea of punishment of Cassiopeia, something like an intervention of rational readjustment. Lucian, ca. 180 A. D. writes, with an ample knowledge and deep experience of the Greek mythological circles, especially in the geographic area of his fatherland Syria, in Palaestina and Cyprus. He is familiar with the phantasy of marine divinities expanded in this region, which also include the rivers Orontes and Euphrates. The Mosaic of Cassiopeia from Apamei-onOrontes with the crowning of Cassiopeia (330-340 A. D.) Antioch and the Mosaic of Andromeda and Perseus from Zeugma attest a kind of triumph of a new version. However, they do not ensure to whom the cradle of the Nereids belongs: Cyprus or Syria. Let us see, what Lucian says in concrete terms. It is surprising that the Nereid Doris is speaking, as if there was a fixed hierarchy in the literature. What the Nereids said is an encomium to tolerance since Lucian offers the key to comprehend that just before this dialogue or even soon after that a new version of Cassiopeia's myth really arose. There must have been a local version, thus a Cypriot myth. The center of the composition could not but be dedicated to Cyprus. On the other hand, it is difficult to accept such a change in the myth without accentuating what Lucian hints: Cassiopeia is exonerated by the Nereids, as she was punished severely out of fear for her daughter. There emerges a new version of the myth which is not attested in literature but it appears in the figurative arts (Apameia, Palmyra, Philippopolis). The Greek text of Lucianus ${ }^{11}$ is as follows:

${ }^{11}$ Floridi 2018: 205-245. 
Dial. Mar. 14, 4:

IФIANA $\Sigma \Sigma$ A 'E

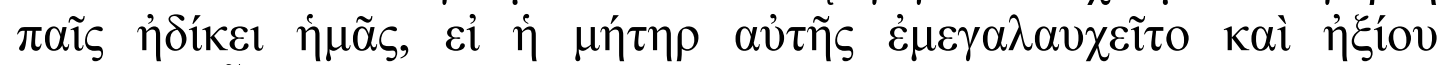

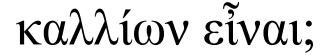

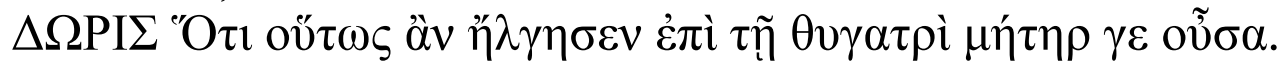

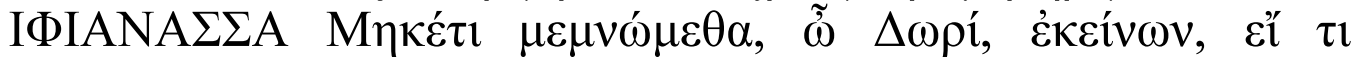

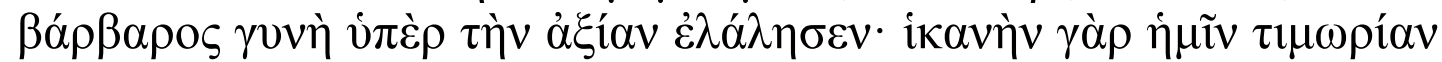

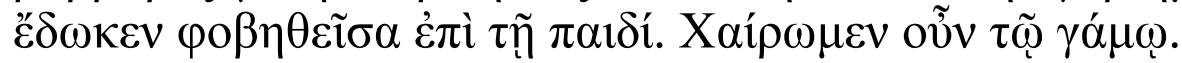

\section{D) The palingenesia of Dionysos}

It is Plutarch who transmits the basic concept in the Mysteries of

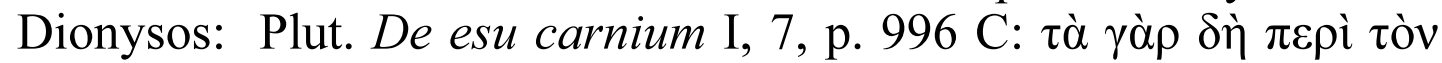

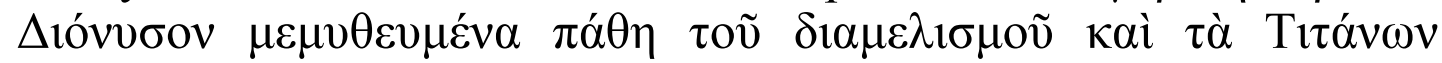

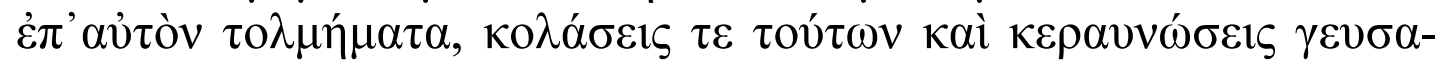

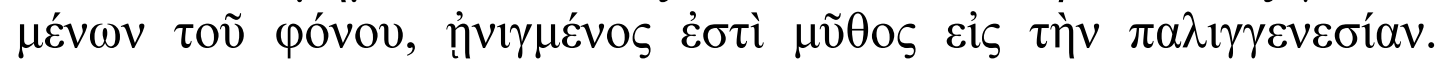
According to Plutarch, the passions of Dionysos, namely the tearing of his body and the aggressions of the Titans, constitute the nucleus of the tale speaking in an apocryphal way on his renaissance, not as Dionysos but as Zagreus. The same concept is attested in Book 13

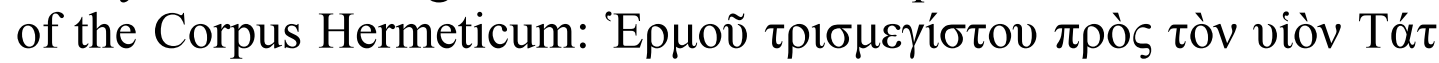

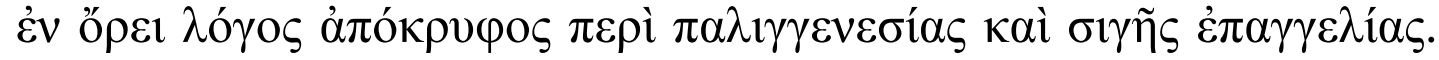
It constitutes the description of the process of divinization through the gnosis acquired by an ecstatic vision. Roman seems to be the political character of the representations according to Plutarch, who

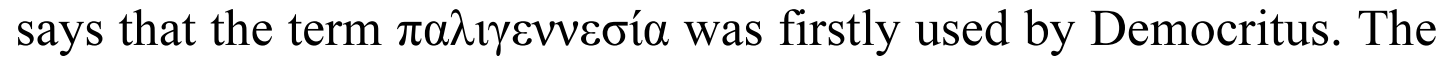
term is normal to the Mysteries of Dionysos, son of Zeus and

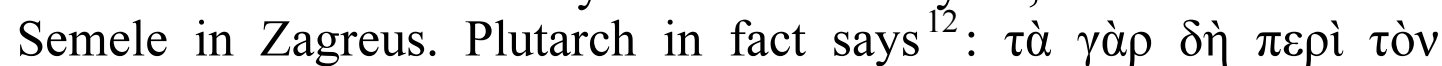

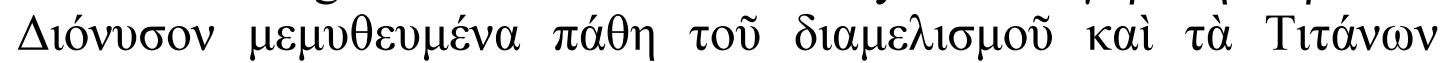

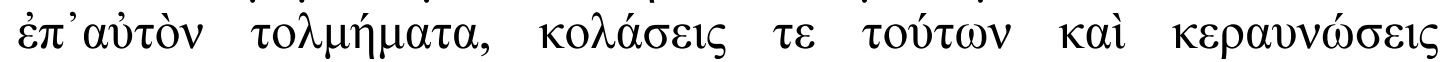

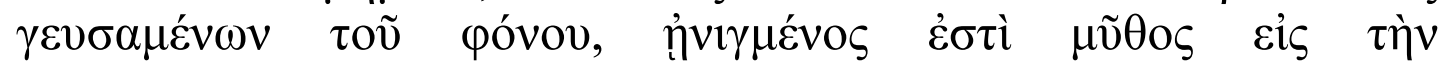

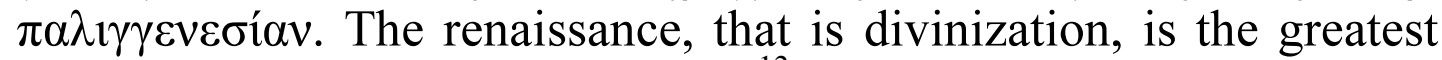

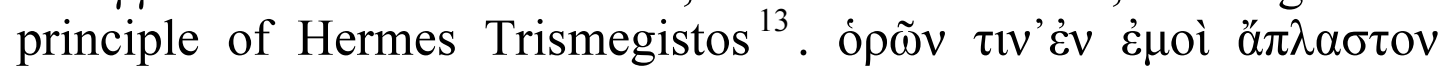

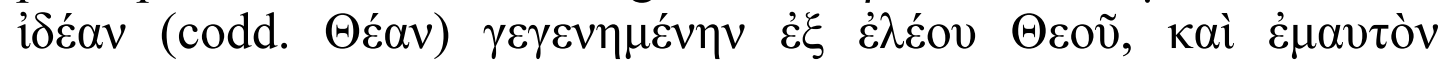

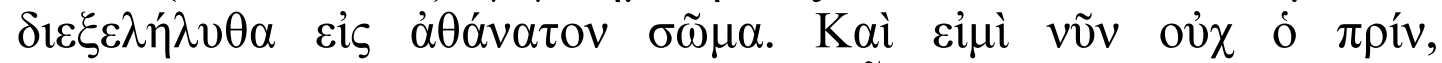

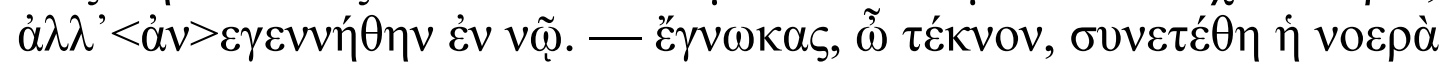

\footnotetext{
${ }^{12}$ Plut. De esu carn. 1, 7 = Moralia 996 C :

${ }^{13}$ W. Scott, Hermetica I. Introduction, Texts and Translation, pp. 238-246:

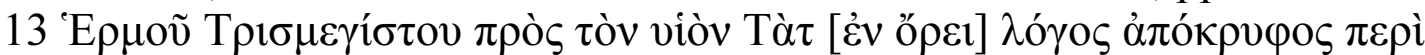

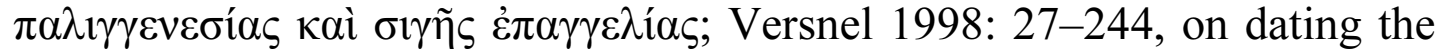
birth of Hermes Trismegistos; Fowden 1986: 22-31, and on Hermetica, pp. $31-44$.
} 


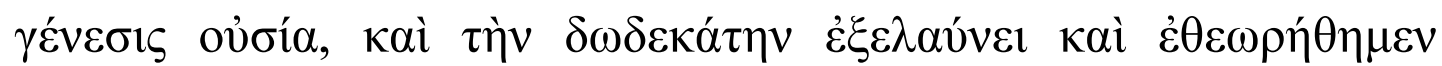

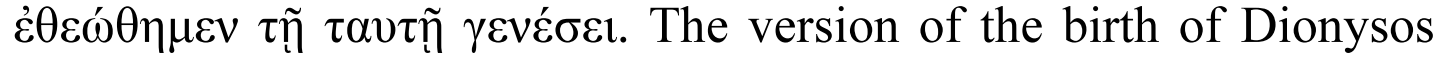
by Hermes testifies that there is an attempt to combine the political renaissance of the Roman Imperium with the private gnosis, on how to save the soul. The independent panels harken back to Mysteries: From Leda and Zeus generated the Dioscuri, whose mysteries connected with the sanctuary of the Kabeiroi in Samothrace, and no less with the Kabeirion in Boeotia, constitute a promise for a new life after death. In this sense the Mysteries of Dionysos and Hermes Trismegistos, should be interpreted.

\section{E) The Roman tradition of the Aion and its political meaning}

I shall try, instead of unveiling apokrypha, to reconstruct the fragments of a lost material chapter of history regarding Roman Cyprus, so as to demonstrate that a concrete iconographic program resulted as part of a wider framework of political events. Thus, we consider the Mosaic as a testimony for the culture emerging in an age of transformations within the society and the religion of Cyprus and the East ${ }^{14}$. After the study of W. Daszewski, even if he promoted Dionysos as the key personality of the whole representation, and despite the fact that the Mosaic is focused on the scene of Aion and Cassiopeia, opinions start to be moving towards every direction of esoteric doctrines without a solid archaeological basis. Some scholars simplify the idea of a historical conflict between Pagans and Christians in Cyprus, which needs to be taken into serious consideration, for such a persistence in the GraecoRoman iconography cannot be random or an instance of contemporary fashion. It expresses an entire world which is still meaningful to the citizens of Nea Paphos. Other scholars tend to oversimplify, by putting forward the idea that there is a general decorative trend appropriate for a triclinium, in any case not a protracted in the time antagonism between ideas on visible Naturalism and Christian symbols. The world of the Invisible takes many pages for any reconstruction. And, whether explicitly expressed or hinted at, only initiated persons could approach the immaterial reality of the metaphysic. On the grounds of the difficulties to overcome, some objective criteria often led to a fundamental misunderstanding on the main concept depicted in the center of the composition: The

\footnotetext{
${ }^{14}$ Iacono 1934.
} 
Greek Aion is thought to have been identical to the Roman Aion ${ }^{15}$, whereas the Roman antiquarian tradition assigns proper religious features which may or may not have been transmitted into the Greek interpretation of 340-350 A. D. ${ }^{16}$ It is a phenomenon of religious and cultural syncretism which occurred sometimes in the past, but it presupposes keeping under constant evaluation what is «Roman» and what is "Greek». Greek is the choice to express concepts through mythological paradeigmata, Greek are the versions of the myths, Greek is their language, but this does not mean that the identity of the owners was Greek, as well. By the time of Aelius Aristides the division was not made between Greeks and Barbarians, but between «Romans» and «not Romans», even in the Greekspeaking East. In fact, what is in the private sphere "Greek» officially speaks «Roman». Thus, the mosaics belong to the Roman Art and not to the Greek Art. This point has some consequences as to who may have the priority among the figurative subjects.

\section{F) The Evidence for praefectus praetorio Flavius Philippus from Chytroi.}

Flavius Philippus is said to have been «second only after the Emperor». Muriel Moser depicted the political situation settled in Rome after Magnetius' hold on Rome. She stresses the honorary statues dedicated to the praefectus praetorio Flavius Philippus. An unpublished inscription from Perge sheds new light into the constitution of a substitute Senatus in Constantinople, in order to delegitimise the position of Magnetius in Rome, by continuing the policy of the Constantinian heritage, as if Constantius II was the new restorer of peace and stability in imitation of his father, Constantine. Magnetius, who came to power for a few months in June 350 A. D., was against Constans but also under threat by Nepotianus in Rome. Nevertheless, in March 350 A. D. the troops of Illyricum proclaimed Vetranius as Emperor. The immediate threat for Constantius was supported by Vulcacius Rufinus, comes Orienti in the early 340's A. D., praefectus praetorio in Italy in 344 A. D., and a little later in the Illyricum. Constantius moved immediately to the West. On 15 March 351 A. D. Constantius II elevated his cousin Gallus to the rank of Caesar in Sirmium, lining up his troops against

\footnotetext{
${ }^{15}$ Zunz 1989; cf. Rochette 1992: 485-488; Foucher 1996: 5-30; Keizer 2000: 53-71; cf. Levi 1944: 269-314.

${ }^{16}$ Moser 2018: Chapter 5; Crisis and Innovation; cf. Forsyth 1912: 51-57.
} 
Magnetius. The new imperial name of Gallus was Caesar Flavius Claudius Constantius Gallus. He married Constantina, Constantius' sister. Constantius succeeded in defeating Magnetius at Mursa in 351 A. D., thus, not accepting Magnetius as co-ruler in the West. Gallus and Constantina set out for Antioch after the battle at Mursa. They were kept under close supervision by Constantius, as he was the new rival, this time in the East. His confident, Thalassius ensured the interests of Constantius as praefectus praetorio per Orientem at Antioch. Two more important persons, Flavius Magnus, proconsul of Asia in 352-353 A. D. and Musonianus proconsul Achaiae in the same years, represented the interests of Constantius in the East ${ }^{17}$. Hence, a new senatorial class was being formed, consisting of personalities deriving from the East, who after having held important magistratures, they constituted the new senatus in Constantinople. This was for the first time an alternative senatus against the senatus in Rome. Several statues were dedicated after the battle of Mursa to the most exceptional supporter of Constantius, the praefectus praetorio Flavius Philippus. We possess an ample part of a fragmentary text of an Oratio ad Senatum, through which Constantius II informed the senators of his wish to erect statues of gold to his praefecto praetorio per Orientem Flavius Philippus, just like in the present case, through a statue erected in his honour at Perge in Pamphylia. This might therefore be the earliest document speaking about the existence of a senatus in Constantinople. The seat of Flavius Philippus was at Antioch, so his move to Constantinople, by changing domicile and being granted citizenship, was due to his election in the new senatus. Three further bases have been found for Philippus, in Ephesus, Alexandria Troas, Cyprus. The base from Ephesus contains the imperial order to a magistrate called Marinus to set up a gilded statue in honour of a close friend of the Emperor, Philippus, who had in several ways contributed to the stability of an Emperor, whose name is $\operatorname{lost}^{18}$. L. Swift and J. Oliver

${ }^{17}$ Barnes 1992: 249-260.

${ }^{18} \mathrm{Ob}$ ha[s igitur] | [causas, patres con]scribti, quae aeternae memoriae mandanda sunt memorabili s[tudio ce]- | [lebrantes tam proba]tam fidem inauratae statuae premiis muneramur quam cele[berrimis] | [locis illi dedica]ndam decernimus uti eius nomen inscribt[um monu]- | [mentis non minus qu]am ipsiu[s for]ma dignationis nostrae gratum fauorem uestr[ique] | [amplissimi coetus] inlustre st[ud]ium perenni commemoratione designet, ut h[ac pri]- | [mum in urbe dignis] uirtutis praemiis donatus merito iudicetur in qua familiae suae fundata[...] | [.......... a]dfectu nostri nominis consecrauit. Et quia non minus eius 
concluded to the name of Constantius II. The importance lies in the dedication of two more statuae inauratae of Flavius Philippus in Cyprus, precisely in Chytroi-Kythrea. The monument was erected at Chytroi by Constantius and his Caesar Gallus (A. D. 351-354) in honour of Flavius Philippus who had been praefectus praetorio per orientem since 344 A. D. ${ }^{19}$
Dd.
$\mathrm{Nn}$.
[C]onstant[ius] victor ac
[T]riumfat[or se]mper Aug. et
Claudius Constantius
Nobili[ssimus C]aesar, pro
Virtutum [hone]st(o) et laboru[m]
Quos in p[raefectur] a emensu[s est,]
Viro clar[issimo] Filippo pr[aef.]
Praetorio[ statua]m ex aere
Fusam aur[oque d] ecoratam
Conloca[ri iusse]runt.

How do we explain this extraordinary honour for the closest friend of the Emperor in Cyprus? Was the choice of Chytroi a random one or did it actually meet certain religious and political requirements, so

laboribus o[mni]-| [um fere ciuitatum] commodis populisq(ue) prospectum e(st) quam patriae nominis nostri, in sing[ulis ur]- | [bibus .........] nsui cura obsequioq(ue) rectorum statuas mirabili uiro erigi a[......] | [placuit, ut huius] effigies omnium semper oculis occurrat cuius deuota officia cunctoru $[\mathrm{m}]$ | [semper mentibus] reuolbuntur. "It is hence for these reasons, Conscript Fathers, namely honouring with a memorable marker that which is necessary to be celebrated in eternal memory, we recompense his proven fidelity with the reward of gilded statues, which we order to be dedicated and erected to him in the most prominent locations, so that his name inscribed on the monuments will not least by its representation reveal in eternal commemoration the thankful grace of our esteem and of the illustrious attention of your very distinguished assembly, so that it will be judged that he has deserved the worthy rewards of his virtues he received first in the city in which he has consecrated the seat of his family on account of his attachment to our name. And because through his labours he has cared for almost all the cities and people no less than he cared for the home city that carries our name, we rule that in all cities [....] statues are to be erected through the care and attention of the governors to this admirable individual $[\ldots]$ and we order that the images of him whose loyal services are always brought back to the memory of all men present themselves always to everyone's eyes»».

${ }^{19}$ Swift, Oliver 1962: 247-264. 
vital for Cyprus? A passage of the Roman - Byzantine Historian Zosimus describes the Roman ritual in honour of the Roman Aion, as it was founded during the aetas regia in Rome itself. The passage is outstanding, not only because it translates the Roman cult into a Greek identity, but also because it attests that at the time of Justinian what was thought to be Aion was nothing else than the original Roman cult of saeculum. This means, without any doubt, that in the time of Constantius II, the Roman saeculum was perceived through the representation of the Greek Aion, and by no means the Hellenistic Aion. The first attestation of Aion in its Roman political meaning appears in the funerary monument of Zoilos at Aphrodisias in Caria. According to Zuntz, Aion would remind of the celebration of the Ludi saeculares by Augustus in 17 B.C. Zoilos must have played a decisive role in the war against Q. Labienus Parthicus in $41 / 40$ B.C., as suggested by the personifications of Av $\delta \rho \varepsilon i \alpha-$ Virtus and Tu$\mu$ - Honos $^{20}$. The political meaning of Aion is decodified by an inscription found at Eleusis $\left(\mathrm{IG} \mathrm{II}^{2} 4705=\mathrm{SIG}^{3}\right.$ $1125)^{21}$. The Eleusis inscription permits to establish a firm connection between Aion and the political power of Rome - sis

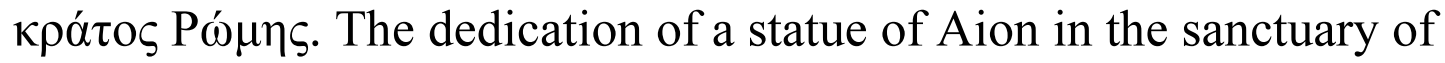
Demetra and Kore at Eleusis is made by Quintus Pompeius, son of

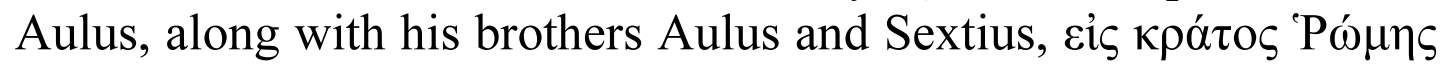

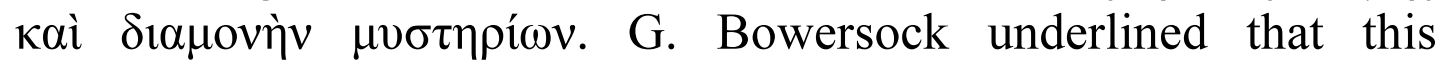
mysteric version of the cult of Aion was deeply rooted in Alexandria by the time of Saint Epiphanius ${ }^{22}$. What the celebration of the Roman saeculum was intended to mean under auspices of the cult of Ditis-Plouton-Aion and Persephone-Kore is actually demonstrated for Late Alexandria, thanks to a passage of Saint Epiphanius the Koreion of Alexandria in the late $4^{\text {th }}$ cent. A. D. The celebration of the feast in Rome in honour of Plouton and Kore is confirmed by Johannes Lydus ${ }^{23}$. The two cults were accompanying in Rome since

${ }^{20}$ Hermary 1995: 542-544; cf. Piganiol 1936: 219-224, on the carmen saeculare, pp. 222-224; Quet 1981: 97-108, 103-108; Lerouge-Cohen 2010: 176-188; Lichtenberger 2015: 110-122, 115-117.

${ }^{21}$ Archaiologike Ephemeris 1887, p. 113, no 33; Graindor 1922: 429-443 : III. Un écho des « Ludi saeculares» à Athènes, pp. 440.

${ }^{22}$ Zuntz 1988: 291-103.

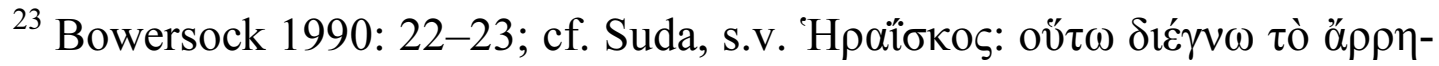

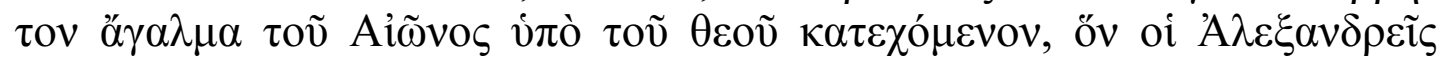

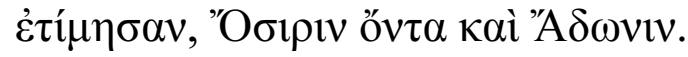


249 B.C. through sacrifices to Dis pater - Plouton and ProserpinaPersephone. And this connection appears in the version of Zosimos, mentioning the aition of the institution of the festival, as being the originary one. Thus, according to the Roman ritual, in the Koreion of Alexandria between 375 and 378 A. D. «torchbearers descend into an underground cavern and come up with a wooden xoanon», distinguished by a gold mark - sphragis in the shape of a cross on its brow». After carrying the image seven times around the temple, they take it back into the underground cavern. The liturgy meant

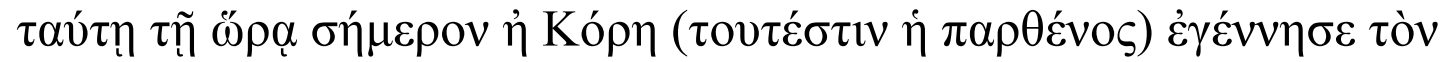
Aī̃va. Bowersock concludes that the Eleusis text, the Aphrodisias frieze, and the Merida mosaic, published by A. Alföldi ${ }^{24}$, «suggest that there was a self-conscious ideological use of Aion in the early empire that was directly connected with the establishment of Roman imperial power».

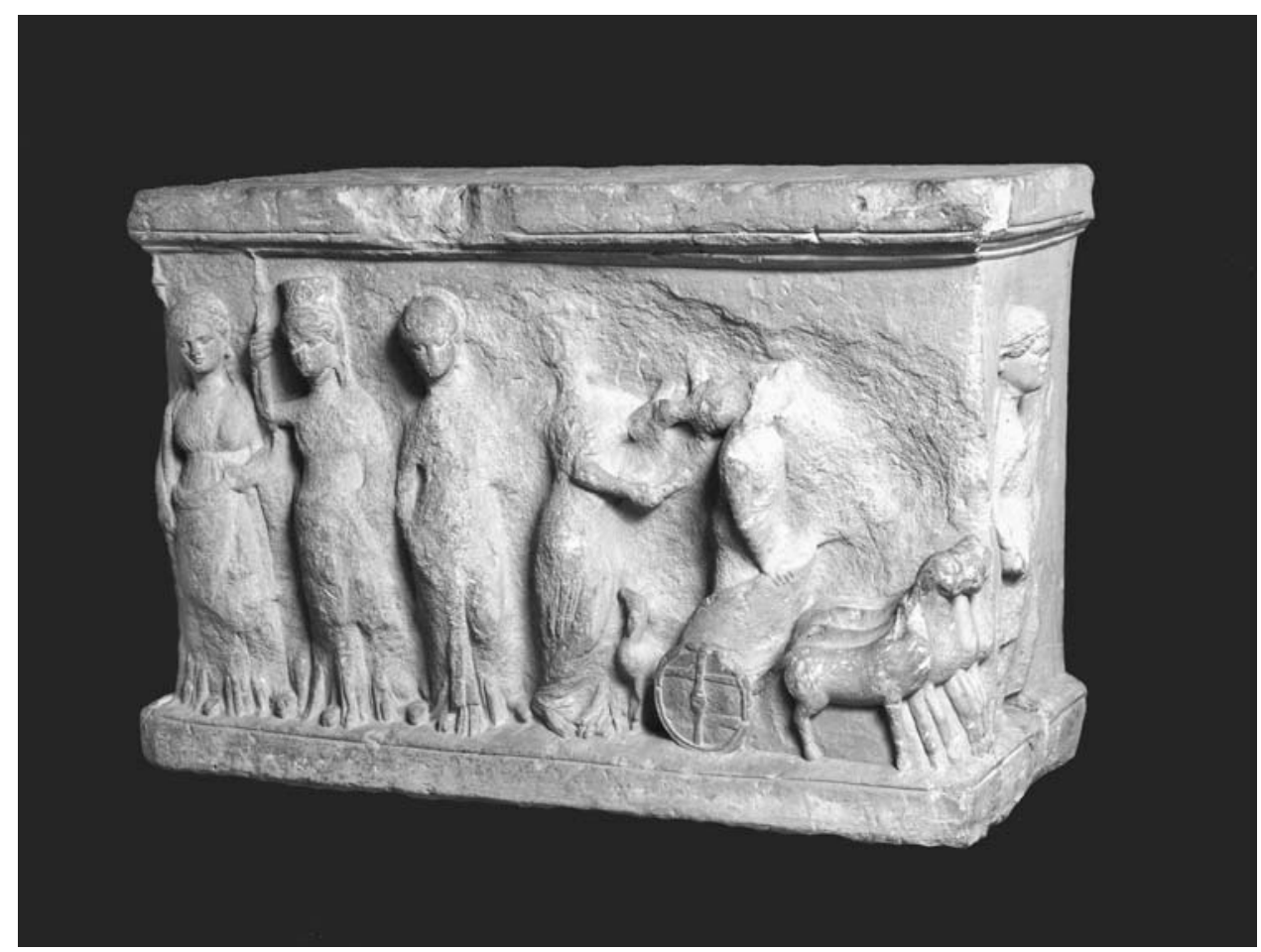

Table 8. An altar from Vitsada, $15 \mathrm{~km}$ away by Chytroi - Kythrea. It is depicted Hekate and the rapt of Propserpina-Kore by Aion-Ploutonios; Cypriot Museum, 140-120 B. C.

${ }^{24}$ Alföldi 1979; Quet 1981: 97-108. 


\section{G) The Ludi saeculares of 348 A. D. in Chytroi - Kythraea?}

Zosimus says that the Ludi saeculares were interrupted, falling into disuse at the time of Diocletianus. The centrality for the Roman imperial ideology had been emerged during the celebration of the Ludi in 248 A. D. by the Emperor Philip the Arab, which coincided with the 1000 years $a b$ Urbe condita $^{25}$. F. Coarelli has demonstrated the two different computes used to settle the celebration of the Ludi, 100 years and 110 years, starting from the rationalization that it took place in $17 \mathrm{~B} . \mathrm{C}^{26}$, since Augustus would not have enough time to celebrate his saeculum aureum still in life. By Claudius it returned to the most accredited tradition. The discovery of the Acta Severiana in 1931 pointed out that Septimius Severus celebrated the Ludi in 204 A. D., according to Augustus compute. By following the compute of 100 years after the celebration of Philipp the Arab in 248 A. D., in the line with the Ludi saeculares celebrated by Claudius in 47 A. D. ${ }^{27}$, we would expect the celebration at the time of Constantius II in 348 A. D. Zosimus said that the Games were not performed at the time of Diocletianus and not even under Constatine according to the Severian compute ${ }^{28}$. The mosaic of Aion from Sahba - Philoppolis, representing Cassiopeia as well, confirms the

${ }^{25}$ Turcan 2014: 151-163: A Re-examination of the reverse of a medaillon stamped in 248 A. D. for the milenary of Rome, which commmerated the Ludi saeculares with racing chariots'.

${ }^{26}$ Coarelli 1991: 211-245.

${ }^{27}$ Tac. Ann. XI, 11; Suet. Claud. 21, 4.

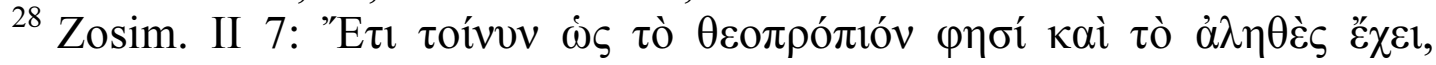

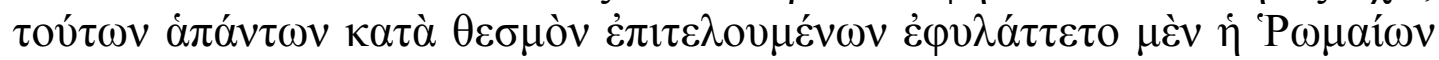

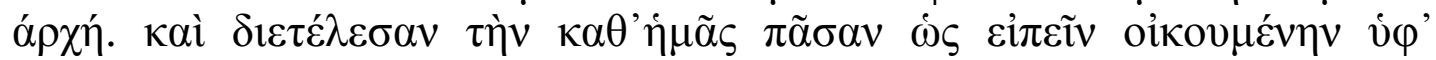

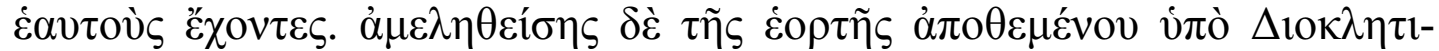

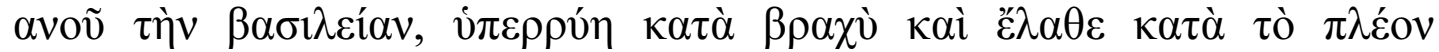

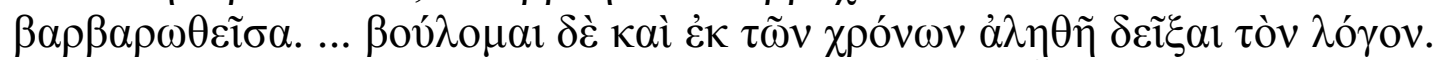

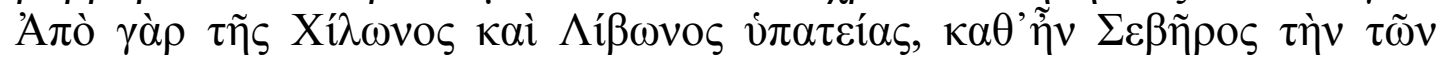

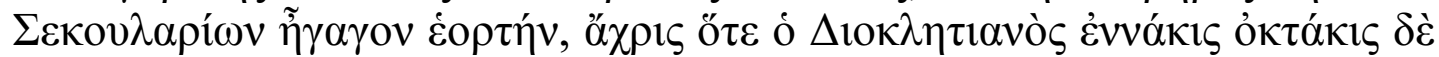

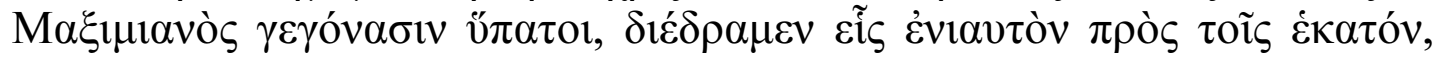

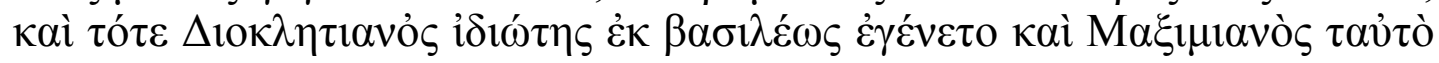

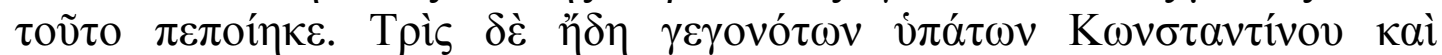

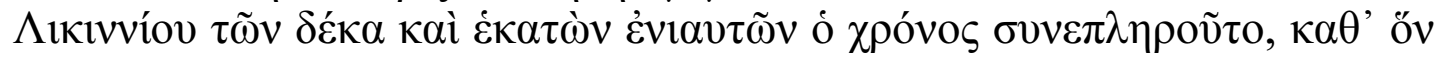

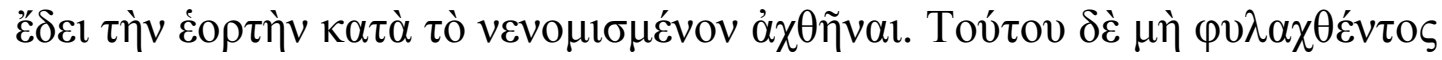

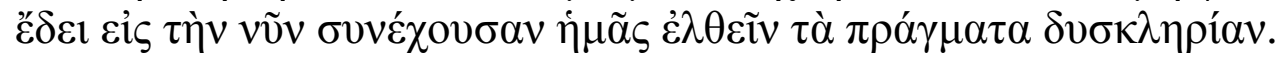


Roman political character of Aion $^{29}$. Otherwise, it is impossible to understand the political meaning without referring to the religious aspect inherent in the Roman festival ${ }^{30}$. The passages which concern it are as follows: (1) Valerius Maximus II, 5: Valesius vir locuples rusticae vitae duobus filiis et filia ad desperationem usque medicorum laborantibus aquam calidam iis a foco petens ... orta deinde vox est, habiturum eos salvos, si continuo flumine Tiberi devectos Tarentum portasset ibique ex Ditis patre et Proserpinae ara petita aqua recreasset. ... et ab eo iussus egredi Tarentum $\uparrow i d$ nomen ei loco est + cupide adrepto calice aquam flumine haustam eo, unde fumus erat obortus, iam laetior pertulit, divinitus dati remedii quasi vestigia quaedam in propinquo nactum se existimans ... dum tenacius omen aprehendit, contractis levibus et quae fors obtulerat nutrimentis pertinaci spiritu flammam evocavit calefactamque aquam pueris bibendam dedit. Qua potato salutari quiete sopiti diutina vi morbi repente sunt liberati patrique indicaverunt vidisse se in somnis a nescio quo deorum spongea corpora sua petergeri et praecipi ut ad Ditis patris et Proserpinae aram, a qua potio ipsis fuerat adlata, furvae hostiae immolarentur lectisterniaque ac ludi nocturni fierent; (2) Zosimus, Hist. II 1-3, about 425-518 A. D.: غ́k

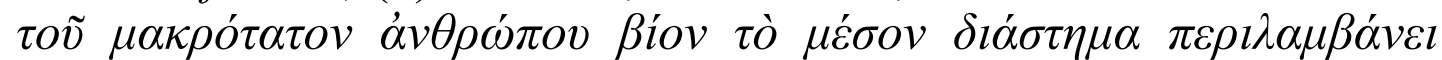

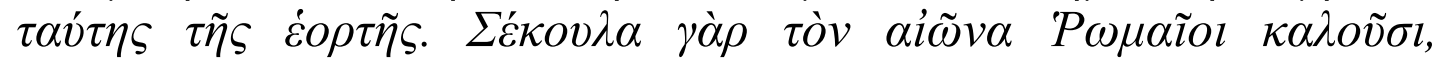

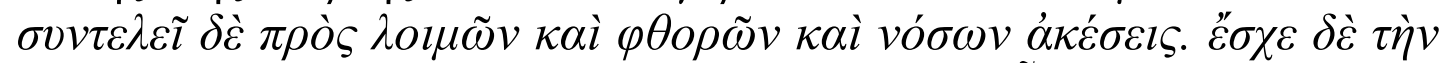

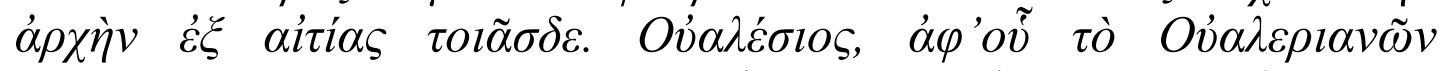

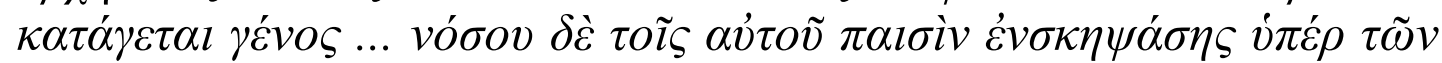

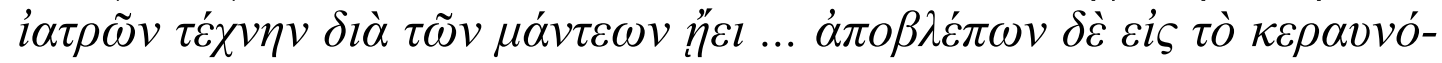

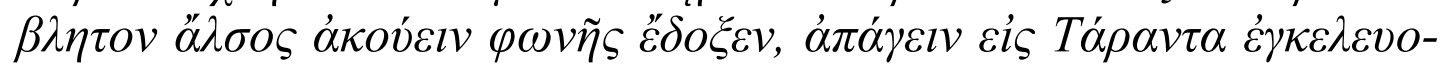

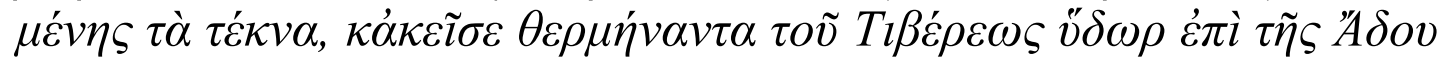

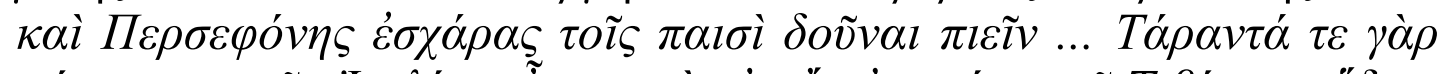

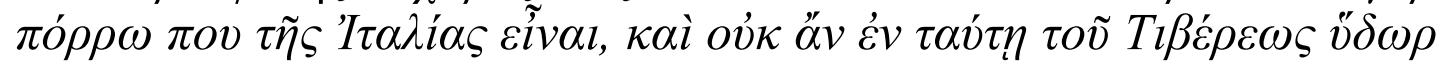

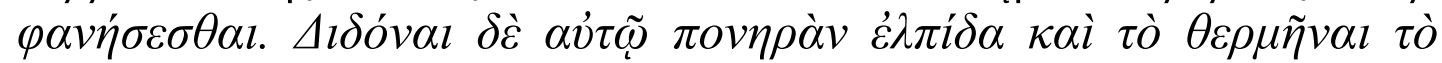

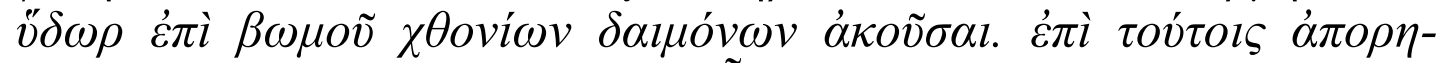

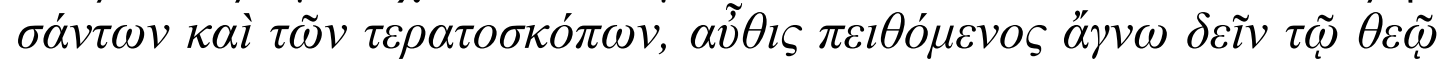

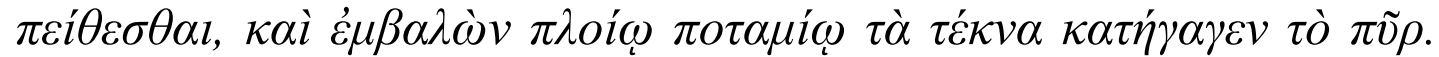

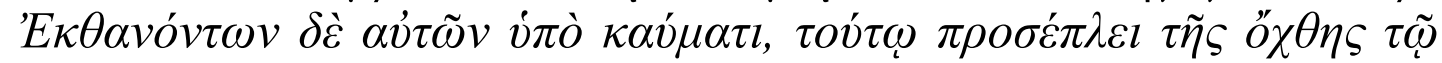

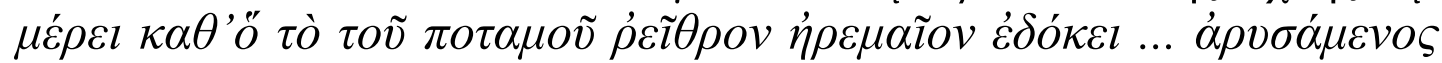

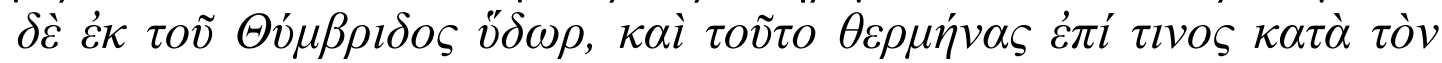

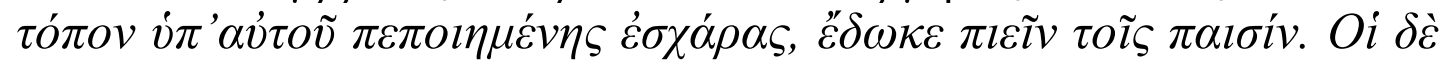

${ }^{29}$ Quet 1999: 269-330; p. 318 : «Philippe l'Arabe n’a pas utilisé la légende Saeculum Aureum»; on saeculum novum and Milliarum saeculum, ibid.

${ }^{30}$ Barker 2015: 161-170. 


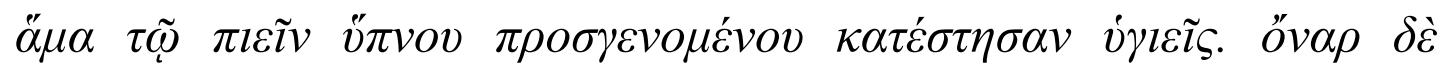

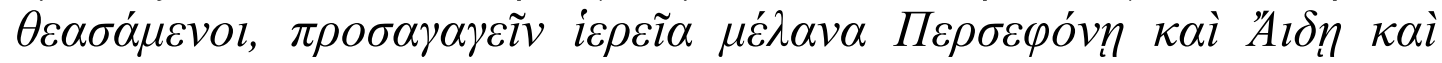

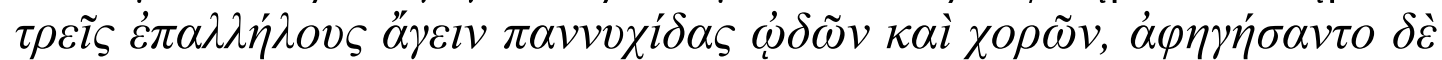

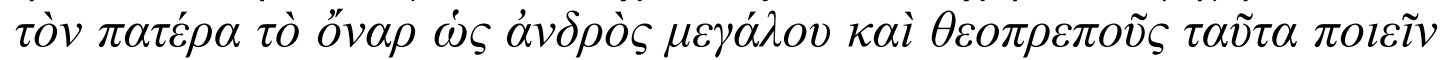

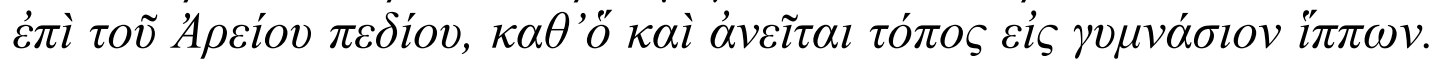

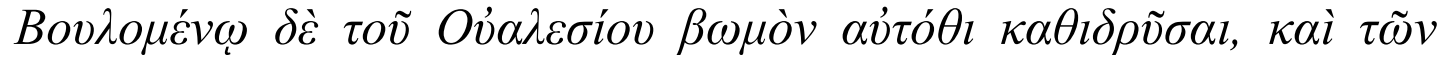

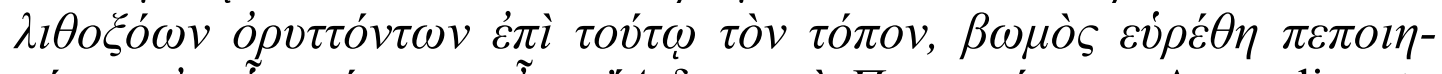

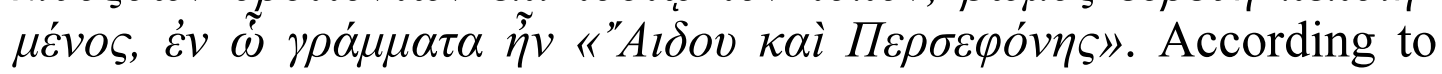
Valerius Maximus and Zosimus the Ludi saeculares had their origin in a sacrificial rite pro valetudine for children born with disabilities, celebrated by the gens Valeria in the Tarentum, in the Campus Martius in Rome. They were performed in the span of 100 years reminding the start of a new saeculum, or new generation, in the $\pi v \rho \varphi$ ó ${ }^{2} v \varepsilon \delta$ íov, where a volcanic water leak moved up in bubbles and an altar dedicated to Plouton and Proserpina - Kore indicated the entrance into the underworld. The first attested celebration falls in 249 B.C., though F. Coarelli reconstructed the historicity of the earliest celebrations. They were next held in 146 B.C. The bella civilia did not permit their celebration in 49 B. C. Then, came Augustus and the quindecimviri must have invented the celebration each 110 years $(456,346,246,126,17$ B. C., the saeculum being taken as lasting 110 years, according to Censorinus (de die nat. 17, 8 Sallman $)^{31}$. The double chronology of reckoning is preserved in the Imperial Times: 47 A. D. under Claudius, 88 A. D., under Domitian, 147 A. D. under Antoninus Pius, 204 A. D. under Septimius

${ }^{31}$ Cens. De die nat. 17, 8-9; Primos enim ludos seaculares exactis regibus post Romam conditam annis CCXLV a Valerio Publicola institutos esse, $<\ldots . . .>$ ad XVvirorum commentariis, anno CCXCVIII M. Valerio Spurio Verginio conss., ....... secondi ludi fuerunt Antia auctore M. Valerio Corvo M. Popilio Laenate IIII> anno post urbem conditam octavo et quadrigentesimo, ut vero in commentariis $X V$ virorum scriptum est anno CCCC et decimo M. Valerio Corvino II C. Poetilio cons. Tertii ludi fuerunt Antiate Lioque auctoribus P. Claudio Pulvhro L. Iumio Pullo cons. <........ > anno quingentesimo duodevincesimo P. Cornelio Lentulo C. Licinio Varo cons. De quartorum ludorum anno triplex opinio est. Antias enim et Varro et Livius relatos esse prodiderunt L. Manlio Censorino M.' Manilio cons. post Romam conditam anno DCV. At Piso Censorius et Cn. Gellius, sed et Cassius Hemina, qui illo tempore vivebat, post annum factos tertium adfirmant Cn. Cornelio Lentulo Lucio Mummio Achaico cons., id est anno DCXXVIII; in XVvirorum autem commentariis notantur sub anno DCXXVIII <M.> Aemilio Lepido L. Aurelio Oreste cons.; Coarelli 1993: 214-215: «sono apocrifi i ludi del 456, 346, 326 e 126». 
Severus, two saecula after the Augustan celebration, 248 A. D. under Philippus the Arab, 262 A. D. under Galienus, whereas in 304 A. D. there arose the intention to celebrate them under Maximianus, but without a known outcome ${ }^{32}$. All we know about Chytroi tends to confirm the presence of «Hot Waters» in the Kefalovryso of Kythraea $^{33}$. An altar found at Vitsada, $10 \mathrm{~km}$ away from Chytroi depicting the Rapt of Proserpina by Plouton, ensures then the presence of a sanctuary dedicated to Demetra, Kore and Plouton, corresponding to the Roman Ditis and Proserpina, in Chytroi. It attests that the dedication to Flavius Philippus was made at Chytroi as self-representation after his labora in Cyprus, which cannot have been but the celebration of the Ludi Saeculares by the "Second magistrate» of the Empire in 348 A. D. The independent dating of the Mosaics of the «House of Aion», after the earthquake of 343 A. D., explains the presence of Aion of the Roman Imperium in the Central panel, during the conflict between Pagans and Christians in Cyprus $^{34}$.

\section{References}

Alföldi, A. 1979: 'Aion in Merida and Aphrodisias', mit Beiträgen von E. Alföldi-Rosenbaum, K. T. Erim und J. Reynolds. Mainz am Rhein.

Balty, J. 1995: Mosaïques antiques du Proche-Orient: chronologie, iconographie, interprétation. Annales littéraires de l'Université de Besançon 551.

Balty, J.-C. 1981: Une version orientale méconnue du mythe de Cassiopée. In: L. Kahill and C. Augé (eds.), Mythologie gréco-romaine, mythologies périphériques. Colloques internationaux du CNRS no. 593. Paris, 95-10;

${ }^{32}$ Bilynskyi Dunning 2016.

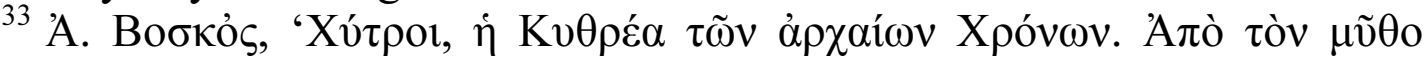

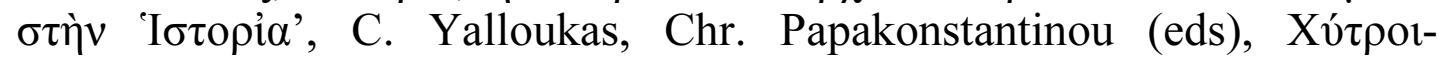

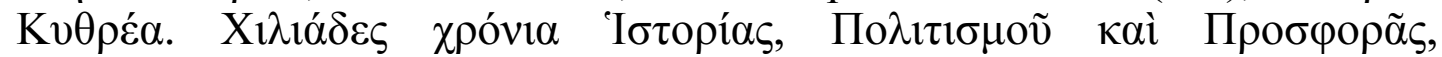

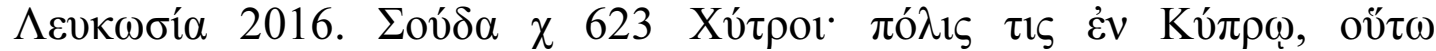

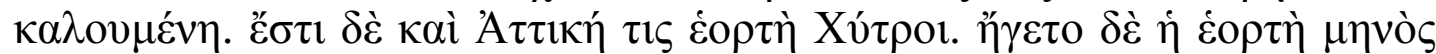

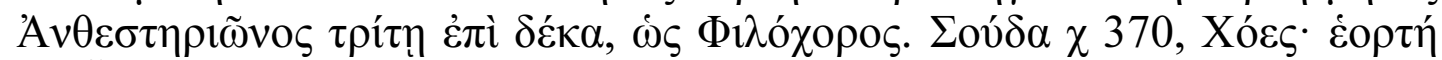

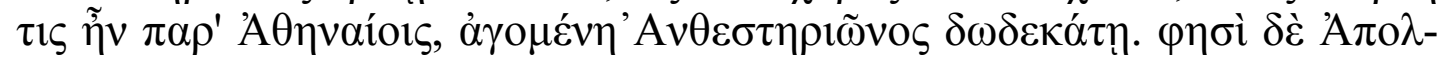

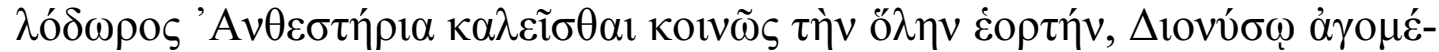

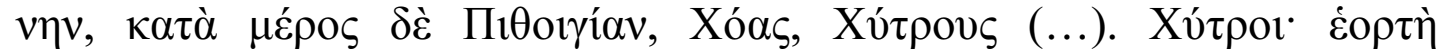

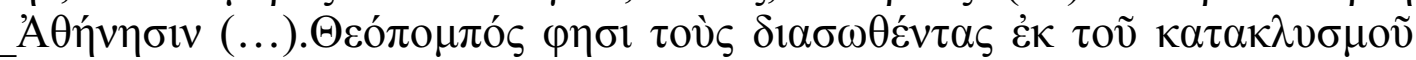

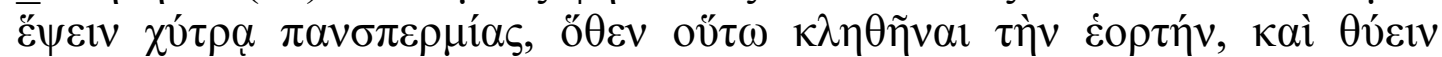

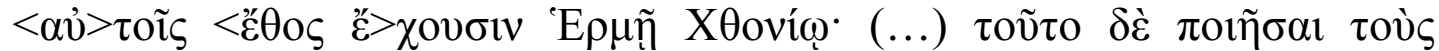

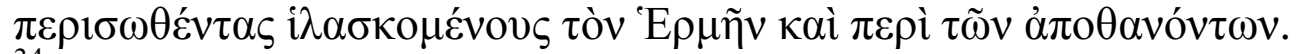

${ }^{34}$ Ladouceur 2018: 50-64. 
Barker, G. 2015: 'The Coinage of Carausius: Developing the Golden Age Ideology through the Saecular Games. The Numismatic Chronicle $175,161-170$.

Barnes, T. D. 1992: 'Praetorian Praefects, 337-361. ZPE 94, 249-260.

Bianchi Bandinelli, R. Roma. 1981³ : La fine dell'arte antica, Milano.

Bilynskyi Dunning S. Chr. 2016: Roman Ludi saeculares from the Republic to Empire (PhD). Toronto.

Bowersock, G. 1990: Hellenism in Late Antiquity. Cambridge.

Bowersock, G. W. 1990: Hellenism in Late antiquity, Cambridge, Ch. IV: Dionysus and His World.

Coarelli, F. 1991: Note sui Ludi saeculares. In: Spectacles sportifs et scéniques dans le monde Etrusco-Italique (Rome, 3-4 Mai 1991), Roma, 1993. 211-245.

Daszewski, W. A. 1985: Dionysos der Erlöser. Griechische Mythen im späten Zypern. Kulturgeschichte der antiken Welt (Sonderband. Trierer Beiträge zur Altertumskunde, Bd. 2), München, 38-45;

Deckers, J. 1986: Dionysos der Erlöser: Bemerkungen zur Deutung der Bodenmosaiken im «Haus des Aion» im Nea Paphos auf Zypern durch W. Daszewski. Römische Quartalschrift für Christliche Altertumskunde und Kirchengeschichte 81, 3, 145-172.

Faulkner, A. 2017: Nonnus' Younger Legend: The Birth of Beröe and the Didactic Tradition. Greece \& Rome 64, 2, 103-114.

Floridi, L. 2018: Luc. DMar 14: 'Perseo e Andromeda tra iconografia e teatro (con un'appendice su DMar 12)'. Aevum Antiquum N.S. 18, 205-245.

Forsyth, G. 1912: Time in Roman Religion. One Thousand Years of Religious History. London, 51-57.

Foucher, L. 1996 : Aiôn, Le Temps absolu'. Latomus 55, 1, 5-30.

Fowden, G. 1986: The Egyptian Hermes. A Historical Approach to the Late Pagan Mind, Princeton.

Graindor, P. 1922: Auguste et Athènes. Révue belge de philologie et d'histoire 1, 3, 429-443.

Hermary, A. 1995: Smith, R. R. R. Aphrodisias I. The Monument of C. Julius Zoilos. L'antiquité Classique 64, 542-544.

Iacono, V. 1934: La ПA Biblica, Commentarii ad rem Biblicam scientifice investigandam, vol. 15.

Kaiser, T. 2011: Interpretations of the Myth of Andromeda at Iope. Syria 88, 323-339.

Keizer, H. M. 2000: 'Eternity' Revisited: A Study of the Greek Word aióv. Philosophia Reformata 65, 53-71;

La Rocca, E. 2021: Hermes - Thoth e Dioniso redentore. Dall'Egitto dei Tolomei al tardo-antico: Studi sul mosaico della Casa di Aion a Nea Paphos (Bullettino della Commissione Comunale Archeologica di Roma, Supplementi, vol. 28). Roma,

Ladouceur, J. 2018: Christians and Pagans in Roman Nea Paphos: Contextualizing the 'House of Aion' Mosaic. UCLA Historical Journal 29, 50-64.

Lerouge-Cohen, Ch. 2010: 'Entre légende monetaire et légende noire: de nouveau sur Q. Labienus Parthicus Imp(erator). Historia 59, 176-188. 
Levi, D. 1944: Aion. Hesperia 13, 269-314.

Lichtenberger, A. 2015: Herod, Zoilos, Philopappos. Multiple Identities in the Graeco-Roman World. Eretz-Israel, 110-122.

Mavrojannis, Th. 2016: 'La Maison de Thésée', à Nea Paphos: Le praetorium de l'époque de Constantin. In: Balandier, C. (ed.) Fondation et développement urbanistique d'une ville chypriote. Bordeaux, 323-347.

Micocka, J. 2013: The Late Roman Insula at Nea Paphos in the Light of New Research'. Athens Journal of History 4, 2, 117-134.

Moser, M. 2018: Emperor and Senators in the reign of Constantius II. Maintaining Imperial Rule Between Rome and Constantinople in the Fourth c. (A.D 350-361), Cambridge.

Nasrallah, L., Luijendik, A.-M., Bakirtzis, Ch. (eds.) 2020: From Roman to Early Christian Cyprus. Studies in Religion and Archaeology, Tübingen.

Olszewski, M. 2013: The Iconographic Programme of the Cyprus Mosaic from the House of Aion reinterpreted as an Anti-Christian Polemic. In: V. Dobrowolski (ed.), Et in Arcadia ego. Studia memoriae Professoris Thomae Micocka dicata, Warsaw, 207-239.

Olszewski, M. 2020: Les figures de rhétorique et l'antithèse dans la narration allégorique de la mosaïque de la Maison d'Aîon à Paphos (Chypre). In: K. Jakouviak, A. Lajtar (eds), Ex Oriente Lux, Studies in Honour of J. Mlynarczyk, Warsau, 221-250 ;

Parrish, D. 1995: A Mythological Theme in the Decoration of Late Roman Dining - Rooms: Dionysos and His Cercle. Revue Archéologique 2, 307-332;

Piganiol, A. 1936: Jeux séculaires. RÉA 38, 219-224.

Quet, M. H. 1999: La mosaïque dite d'Aiôn de Shahba - Philippopolis. Philippe l'Arabe et la conception Hellène de l'ordre du monde, en Arabie, à l'aube du Christianisme. Cahiers du Centre Gustave Glotz 10, 269-330.

Quet, M.-H. 1981: Aîon. À propos d'un livre récent'. RÉA 83, 97-108.

Rochette, Br. L'Antiquité Classique 61, 485-488.

Scott, W. Hermetica I. Introduction, Texts and Translation, 238-246

Swift, L. J., Oliver, J. 1962: Constantius on Flavius Philippus. AJPh 83, 247-264.

Turcan, R. 2014 : Le millénaire de Rome au Grand Cirque; un cas de condensé symbolique. Journal des Savants, 151-163.

Versnel, H. 1998: Inconsistencies in Greek and Roman Religions. Volume 1. Ter Unus, Leiden, 27-244.

Zuntz, G. 1988: Aion Ploutonios. Hermes 116, 291-103.

Zunz, G. 1992: 'Aion, Gott des Römerreichs', Heidelberg. 